\title{
A SEMANTIC ANALYSIS OF DEIXIS IN DRAMA WRITTEN BY LUCILLE FLETCHER ${ }^{1}$
}

\author{
Sukasih Ratna Widayanti, Suhud Eko Yuwono \\ English Education Study Program, Universitas Widya Dharma Klaten \\ ratna@unwidha.ac.id
}

\begin{abstract}
This study purposes to describe the forms of deixis in the drama written by Lucille Fletcher. This is descriptive qualitative study. The sources of the data are in the form of word and phrase in the drama script entitled Sorry, Wrong Number written by Lucille Fletcher. Based on the data findings, the form of deixis in the drama script Lucille Fletcher's Sorry, Wrong Number are the person deixis, place deixis, time deixis, and social deixis. The highest occurrence on the forms of deixis in Lucille Fletcher's Sorry, Wrong Number is person deixis. It means that person deixis is the most common type used by the characters in Lucille Fletcher's Sorry, Wrong Number to communicate between each character in order to deliver their message due to the plot of the drama.
\end{abstract}

Keywords: semantics, deixis, drama

\section{INTRODUCTION}

Language is a system of human communication since communication, itself, is something important in human life. Human cannot live alone, so they need other people in their life. It means that they have to communicate each other. People use language as the instrument of communication to deliver their thought in their mind and their message toward something. To make the communication can be understood by both the speaker and hearer of a language, they must use the same language.

In communication, there are some aspects of language that must be noticed. One of them is the study of deixis. Deixis is a technical term from Greek. Essentially, deixis is concerned with the way

\footnotetext{
${ }^{1}$ Widayanti, Sukasih Ratna dan Yuwono, Suhud Eko. 2017. A Semantic Analysis of Deixis in Drama Written by Lucille Fletcher. Laporan Penelitian: Universitas Widya Dharma Klaten.
} 
in which language is encoded or grammatical features of the context of utterance in the speech event. It is also concerned with the ways in the interpretation of utterances depends on the analysis of that context of utterance (Levinson, 1983:62). It is a word which takes some elements of its meaning form the situation of the utterance in which it is used. One example is when we point to an object and say 'This is a pen.', so we use the deixis term. Interpreting deixis depends on both speaker's and listener's interpretation in the same context. One example is in the sentence, "I'll put this here." This utterance will easily understand by people who involved in the conversation. In the other hand, it will difficult to understand by other who did not involve in the conversation.

Communication can also deliver through the literary work, such as novel, drama, poetry, and short stories. The author communicates with the reader through the use of the language. Drama as one of literary work is the manifestation of an active attitude of the author to address matters of human beings. The use of language in Lucille Fletcher's Sorry, Wrong Number generates the social meaning. The author shows the ability in using language in a series of word in a drama. A word can be said as deixis if the reference is moving or changing, depending on the time and place of the word spoken. Some examples are the word 'I', 'here', and 'now'. Lyons (1995:270) states that deixis used to deal with the characteristics of determination language related to time and place.

Based on the limitation of the problem, the problem of this study can be formulated as follows 'What are the the forms of deixis in the drama written by Lucille Fletcher?' Related to the formulation

of the problem, the objective of this study is to describe the forms of deixis in the drama written by Lucille Fletcher.

Based on the explanation above, the writer are interested in analyzing the deixis in the drama. Hence, the writer want to conduct a research entitled 'A Semantic Analysis of Deixis in Drama Written By Lucille Fletcher'

\section{METHOD}

\section{Research Design}

This study employs a descriptive qualitative method. A qualitative design refers to a research procedure which produces descriptive data. Bogdan and Taylor (1975: 4) state that human being's written or spoken words and their observable behaviours are the examples of the descriptive data. A 
descriptive research is a method that deals with the possibilities to solve an actual problem by collecting, classifying, analyzing, and interpreting data (Surachmad, 1994: 147).

Merriam (2009:14-16) states that there are four characteristics which are identified by most as key to understanding the nature of qualitative research. Firstly, the focus is on process, understanding, and meaning. Secondly, the researcher is the primary instrument of data collection and analysis. Thirdly, the process is inductive. Lastly, the product is richly descriptive.

\section{Source of the Data}

The sources of the data in this study are the drama script of Lucille Fletcher's Sorry, Wrong Number. The data sources in this study are in the form of words, phrases, and sentences which is written in the drama script.

A descriptive (especially qualitative) research has a natural setting as the direct source and the researcher is the key instrument (Bogdan and Biklen, 1982: 27). Thus, the writer are the main instrument in this research. The secondary instrument was data sheet which is also used to identify and analyse the data.

\section{Data Collection Technique}

In this study, the writer use documentation as the technique of collecting the data. The writer collect the data by gathering the document of the utterance indicating the deixis, which is written in the drama script. Firstly, the writer read the drama carefully in order to find out the words related to the kinds of deixis and their references. The next step underlines the deixis which is found in the drama script. Then, the data categorizes into their types.

\section{Data Analysis Technique}

In analyzing data, the writer use flow model. Miles and Huberman (2007:20) states that the analysis consists of three concurrent flows of activity. They are data reduction, data display, and conclusion drawing or verification. The first is data reduction which refers to the process of selecting, focusing, simplifying, abstracting and transforming the "raw" data that appears in written-up field notes. The second is data display. Data display is defined as organized and action taking. The third stream of analysis activity is conclusion drawing and verification. 
For the data analysis technique, the researchers use the descriptive analysis to interpret the data. The collected data identifies and classifies based on the types of deixis found in the drama script. In this study, the writer use some steps to analyze data as follow. First, the writer collect the data by underlining the deixis form in the drama transcript. Second, the writer classify the data into the types of deixis. Third, the writer count the number of each type of deixis. Last, the writer make conclusion due to the data.

\section{RESULT AND DISCUSSION}

After collecting and analyzing the data, there are four types of deixis that occur in the drama script of Lucille Fletcher's Sorry, Wrong Number. They include person deixis, place deixis, time deixis, and social deixis. In this study, the number of the data on the types of deixis which occur in the drama script of Lucille Fletcher's Sorry, Wrong Number is 397. Table 5 below shows the complete data findings on the occurrences of the types of deixis in the drama script of Lucille Fletcher's Sorry, Wrong Number.

Table 1. The Frequency of Occurrences of the Form of Deixis

\begin{tabular}{clc}
\hline No. & Types of Deixis & Frequency \\
\hline 1 & Person Deixis & 276 \\
2 & Place Deixis & 71 \\
3 & Time Deixis & 43 \\
4 & Social Deixis & 7 \\
& Total & $\mathbf{3 9 7}$
\end{tabular}

Based on the table 5 above, it is found that there are 397 data indicating deixis. The highest percentage of the occurrence on the types of deixis in Lucille Fletcher's Sorry, Wrong Number is person deixis. There are 276 out of 397 utterances or about $69.5 \%$. It means that person deixis is the most common type used by the characters in Lucille Fletcher's Sorry, Wrong Number to communicate between each character to deliver their message due to the plot of the drama.

The second level of occurrence is place deixis. This type is used 71 times by the characters in this drama out of 397 data or about 17.9\%. The drama entitled Sorry, Wrong Number also states the name of common places in New York as the setting of place in the play. 
The third percentage of the occurrence is time deixis. In Lucille Fletcher's Sorry, Wrong Number's script, there are 43 out of 397 utterances or about $10.8 \%$. The adverb of time is also stated by the writer Lucille Fletcher as the setting of time in the drama entitled Sorry, Wrong Number. It describes what time is the conversation taken place in the play.

The last type of deixis is social deixis. It is the lowest percentage of the occurrence on the types of deixis in Lucille Fletcher's Sorry, Wrong Number. It is used by the characters in this drama for 7 times out of 397 utterances or about $1.8 \%$. It shows the social relationship between the characters.

In this study, the data of person deixis can classify based on its form. They are subject pronoun, object pronoun, possessive adjective, possessive pronoun, and reflexive pronoun. Form the data finding, the subject pronouns which occur in the drama script of Lucille Fletcher's Sorry, Wrong Number are I, you, we, they, he, she, and it. The object pronouns which occur in the drama script of Lucille Fletcher's Sorry, Wrong Number are me, you, us, them, him, her, and it. The possessive adjectives also show in the drama script of Lucille Fletcher's Sorry, Wrong Number. They are my, your, our, their, and her. The possessive pronoun which occurs in the drama script of Lucille Fletcher's Sorry, Wrong Number is 'mine'. 'Myself' is one reflexive pronoun which occurs in the drama script of Lucille Fletcher's Sorry, Wrong Number.

Below is the data finding of each type of deixis.

\section{Person Deixis}

The person deixis can classify into some forms, such as subject pronoun, object pronoun, possessive adjective, and reflexive pronouns. The explanation of each form is taken from the data in drama script of Lucille Fletcher's Sorry, Wrong Number.

a. Subject Pronoun 'I'

Here are some examples of subject pronoun 'I' in this study. Data 3) Mrs. Stevenson: Operator? I have been dialing .... But I don't see .... The data 3) is happened when Mrs. Stevenson tries to call her husband's office but the line is always busy.

Data 9) Mrs. Stevenson: I don't see how it could be .... He's working late tonight and I' $m$ all alone here in the house. My health is very poor and I've been feeling .... The data 9) is also stated by Mrs. Stevenson who still feels worried why her husband's office cannot be contacted. 


\section{b. Subject Pronoun 'you'}

Here is the example of subject pronoun 'you' in drama script of Lucille Fletcher's Sorry, Wrong Number. Data 61) Mrs. Stevenson: .... And you dialed it. And we've got to find out .... The subject pronoun 'you' refers to the operator who is talking to Mrs. Stevenson.

c. Subject Pronoun 'we'

Here is the example of subject pronoun 'we' in this study. Data 21) $1^{\text {st }}$ man: We have heard from our client. He says the coast is clear for tonight. The subject pronoun 'we' refers to the man and his friend.

d. Subject Pronoun 'they'

Here is the example of subject pronoun 'they' in drama script of Lucille Fletcher's Sorry, Wrong Number. Data 70) Mrs. Stevenson: .... -and I could hear them, but they couldn't hear $m e$. The subject pronoun 'they' refers to the men who are talking about murder and Mrs. Stevenson hears the conversation.

e. Subject Pronoun 'he'

Here is the example of subject pronoun 'he' in this study. Data 13) Mrs. Stevenson: .... He's working late tonight and .... The subject pronoun 'he' refers to Mr. Elbert Stevenson.

f. Subject Pronoun 'she'

Here is the example of subject pronoun 'she' in drama script of Lucille Fletcher's Sorry, Wrong Number. Data 36) $1^{\text {st }}$ man: .... It makes a noise in case her window is open, and she should scream. The subject pronoun 'she' refers to Mrs. Stevenson.

\section{g. Subject Pronoun 'it'}

Here is the example of subject pronoun 'it' in this study. Data 11) Mrs. Stevenson: .... It's my husband's office. He's .... The subject pronoun 'it' refers to Mr. Stevenson's office.

h. Object Pronoun 'me'

Here is the example of object pronoun 'me' in this study. Data 8) Mrs. Stevenson: .... Will you try it for me, please? The object pronoun 'me' refers to Mrs. Stevenson.

i. Object Pronoun 'you'

Here is the example of object pronoun 'you' in drama script of Lucille Fletcher's Sorry, Wrong Number. Data 73) Operator: Murray Hill 4-0098? I will try to get it for you, madam. The object pronoun 'you' refers to Mrs. Stevenson. 


\section{j. Object Pronoun 'us'}

Here is the example of object pronoun 'us' in this study. Data 344) Woman: .... -and our superintendent has asked us to send people out only on .... The object pronoun 'us' refers to the woman and her friend.

k. Object Pronoun 'them'

Here is the example of object pronoun 'them' in drama script of Lucille Fletcher's Sorry, Wrong Number. Data 69) Mrs. Stevenson: .... -and I could hear them, but they couldn't hear me.... The object pronoun 'them' refers to the men who are talking about murder and Mrs. Stevenson hears the conversation.

1. Object Pronoun 'him'

Here is the example of object pronoun 'him' in this study. Data 175) Mrs. Stevenson: ...., and I was trying to reach him to ask him to come home... The object pronoun 'him' refers to Mr. Stevenson.

m. Object Pronoun 'her'

Here is the example of object pronoun 'her' in drama script of Lucille Fletcher's Sorry, Wrong Number. Data 21) $1^{\text {st }}$ man: .... Our client does not wish to make her suffer long. The object pronoun 'her' refers to Mrs. Stevenson.

n. Object Pronoun 'it'

Here is the example of object pronoun 'it' in this study. Data 62) Mrs. Stevenson: .... And you dialed it. And we've got to .... The object pronoun 'it' refers to the telephone number of Mr. Stevenson's office.

o. Possessive Adjective 'my'

Here is the example of possessive adjective 'my' in drama script of Lucille Fletcher's Sorry, Wrong Number. Data 224) Mrs. Stevenson: .... -she's too lazy to bring up my breakfast tray-and

p. Possessive Adjective 'your'

Here is the example of possessive adjective 'your' in this study. Data 20) Operator: Your call, please? 
q. Possessive Adjective 'our'

Here is the example of possessive adjective 'our' in drama script of Lucille Fletcher's Sorry, Wrong Number. Data 22) $1^{\text {st }}$ man: We have heard from our client. He says the coast is clear for tonight.

r. Possessive Adjective 'their'

Here is the example of possessive adjective 'their' in this study. Data 147) Mrs. Stevenson: It was a perfectly definite murder. I heard their plans distinctly....

s. Possessive Adjective 'her'

Here is the example of possessive adjective 'her' in drama script of Lucille Fletcher's Sorry, Wrong Number. Data 35) $1^{\text {st }}$ man: .... It makes a noise in case her window is open, and she should scream.

t. Possessive Pronoun 'mine'

Here is the example of possessive pronoun 'mine' in this study. Data 239) Mrs. Stevenson: .... And warn your radio cars to watch out-especially in suspicious neighborhoods like mine?

u. Reflexive Pronoun 'myself'

Here is the example of reflexive pronoun 'myself' in drama script of Lucille Fletcher's Sorry, Wrong Number. Data 143) Mrs. Stevenson: .... I've been trying to trace down the call myself, but ....

\section{Place Deixis}

Place deixis states the location where the speech event between the speaker and hearer is happened. Here is one example of the occurrence of place deixis in this study. The following utterance in data 16) spoken by Mrs. Stevenson indicates the occurrence of place deixis.

Data 16. Mrs. Stevenson: I don't see how it could be busy all this time. It's my husband's office. He's working late tonight and I'm all alone here in the house. My health is very poor and I've been feeling so nervous all day ....

The phrase 'in the house' in data 16) shows the occurrence of place deixis. It indicates the location where Mrs. Stevenson is alone without her husband. 


\section{Time Deixis}

Time deixis functions to locate the interval of time when the speech event is happened. Here are some examples of the occurrence of time deixis in this study. The following utterance in data 5) indicates the occurrence of time deixis.

Data 5. Mrs. Stevenson: Operator? I have been dialing Murray Hill 4-0098 now for the last three quarters of an hour, and the line is always busy. But I don't see how it could be busy that long. Will you try it for me, please?

The word 'now' and the phrase 'for the last three quarters of an hour' in data 5) show the time deixis. The word 'now' means at the present time, not in the past or future. The phrase 'for the last three quarters of an hour' also indicates the time that Mrs. Stevenson tries to call her husband.

\section{Social Deixis}

Social deixis shows the social relationship between the characters in the drama entitled Sorry, Wrong Number. Here is one example of the occurrence of social deixis in this study. The social relation is the relationship of husband and wife. It can be seen in the data 12) where Mrs. Stevenson tell the operator about trying to call her husband office since her husband is working late tonight. The following utterance in data 12) spoken by Mrs. Stevenson indicates the occurrence of social deixis.

Data 12. Mrs. Stevenson: I don't see how it could be busy all this time. It's my husband's office. He's working late tonight and I'm all alone here in the house. My health is very poor and I've been feeling so nervous all day ....

The phrase 'my husband' show the social relation of Mrs. Stevenson and her partner or her husband. She addresses him with the term 'my husband' rather than says the complete name 'Mr. Stevenson'.

\section{CONCLUSION}

Based on the data findings, the types of deixis in the drama script Lucille Fletcher's Sorry, Wrong Number are the person deixis, place deixis, time deixis, and social deixis. The total data is 397 indicating deixis. The highest percentage of the occurrence on the types of deixis in Lucille Fletcher's Sorry, Wrong Number is person deixis. There are 276 out of 397 utterances or about $69.5 \%$. It means 
that person deixis is the most common type used by the characters in Lucille Fletcher's Sorry, Wrong Number to communicate each other. The second level of occurrence is place deixis. This type is used 71 times by the characters in this drama out of 397 data or about $17.9 \%$. The third percentage of the occurrence is time deixis. In Sorry, Wrong Number's script, there are 43 out of 397 utterances or about $10.8 \%$. The last type of deixis is social deixis. It is used by the characters in this drama for 7 times out of 397 utterances or about $1.8 \%$.

\section{REFERENCE}

Bogdan, R., and Biklen, S. 1982. Qualitative Research for Education: An Introduction to Theory and Method. Boston: Allyn and Bacon, Inc.

Bright, William. 1992. International Encyclopedia of Linguistics. London: Oxford University Press.

Cruse, Alan. 2000. Meaning in Language: An Introduction to Semantics and Pragmatics. New York: Oxford University Press Inc.

Cruse, Alan. 2006. A Glossary of Semantics and Pragmatics. Edinburgh: Edinburgh University Press.

Griffiths, Patrick. 2006. An Introduction to English Semantics and Pragmatics. Edinburgh: Edinburgh University Press.

Hipkiss, Robert. A. 1995. Semantics: Defining the Discipline. Lawrence: Lawrence Erlbaum Associates.

Hurford, James R and Heasley, Brendan. 1983. Semantics: A Coursebook. Cambridge: Cambridge University Press.

Hurford, James R., Branden Haesley, and Michael B. Smith. 2007. Semantics a Course book: $2^{\text {nd }}$ edition. New York: Cambridge University Press.

Katz, J. 1972. Semantic Theory. New York: Harper and Row.

Kreidler, Charles. W. 1998. Introducing English Semantics. London: Routledge.

Leech, G. 1974. Semantics. London: Penguin.

Levinson, Stephen. C. 1983. Pragmatics. New York: Cambridge University Press. 
Lyons, John. 1995. Linguistic Semantics: An Introduction. Cambridge: Cambridge University Press.

Merriam, Sharan B. 2009. Qualitative Research: A Guide to Design and Implementation. San Fransisco: John Wiley and Sons, Inc.

Miles, Mathew B. and Huberman, Michael A. 2007. Analisis Data Kualitatif (Translated Edition). Jakarta: Universitas Indonesia.

Palmer, F.R. 1981. Semantics. Sydney: Cambridge University Press.

Reimer, Nick. 2010. Introducing Semantics. New York: Cambridge University Press.

Saeed, John. I. 2003. Semantics: $2^{\text {nd }}$ edition. Australia: Blackwell Publishing Ltd.

Surachmad, Winarno. 1994. Dasar dan Teknik Research: Pengantar Metodologi Ilmiah. Bandung: CV. Tarsito.

Szabo, Zolton Gendler. 2005. Semantics vs. Pragmatics. New York: Oxford University

Press Inc. 